Article

\title{
Properties of Wood Particleboards Containing Giant Reed (Arundo donax L.) Particles
}

\author{
Manuel Ferrandez-Villena *(1), Antonio Ferrandez-Garcia, Teresa Garcia-Ortuño, \\ Clara Eugenia Ferrandez-Garcia and Maria Teresa Ferrandez Garcia \\ Department of Engineering, Universidad Miguel Hernandez, 03300 Orihuela, Spain; \\ antonio.ferrandezg@umh.es (A.F.-G.); tgarcia@umh.es (T.G.-O.); cferrandez@umh.es (C.E.F.-G.); \\ mt.ferrandez@umh.es (M.T.F.G.) \\ * Correspondence: m.ferrandez@umh.es; Tel.: +34-966-749-716
}

Received: 10 November 2020; Accepted: 11 December 2020; Published: 15 December 2020

\begin{abstract}
Agriculture is responsible for generating large amounts of waste that are not adequately managed in terms of their environmental treatment and economic administration. This work uses giant reed, which was traditionally used as a construction material in eastern areas of Spain. Nowadays, it is no longer used, which has led to its rapid, autonomous, uncontrolled proliferation on river banks, making it a serious environmental hazard because this plant causes significant blockages of bridges and other infrastructure when uprooted by the strong currents that occur as rivers flood. The aim of this work is to develop wood and giant reed particleboards, which help to counter the high dependence on wood in industrial manufacturing by using an easily renewable resource. It will thereby be possible to achieve two general objectives: controlling the growth of a weed and obtaining a product (particleboards) from a waste material. Particleboards containing $9 \%$ urea formaldehyde composed of different proportions of sawmill wood and giant reed $(0,50,70$ and $100 \%)$ have been manufactured by applying two different pressures $(2.1$ and $2.6 \mathrm{MPa})$ and a temperature of $120^{\circ} \mathrm{C}$ for $4 \mathrm{~min}$ in a hot plate press. Density, thickness swelling (TS) and water absorption (WA) after immersion in water, modulus of elasticity (MOE), modulus of rupture (MOR), internal bonding strength (IB) and screw holding strength (SH) have been tested according to european norms (EN) for wood boards. With the addition of 70\% reed particles, the density, MOR and TS decrease and the MOE, IB and SH increase; therefore, adding giant reed particles to wood boards can improve their properties, bringing about considerable industrial and environmental benefits.
\end{abstract}

Keywords: plant waste; particleboards; physical; mechanical and thermal properties

\section{Introduction}

Wood is the most widely used lignocellulosic material in pulp manufacture, the furniture industry, the construction industry and as fuel. Every year, a surface area of 11 million hectares of forest is lost globally due to the production of wood for industrial and fuel purposes, in addition to the deforestation caused by the expansion of pastures, crops and urban development [1]; it is therefore an environmental problem.

According to the European "EUwood" study [2], wood consumption for energy generation is expected to increase from a solid volume of 346 million $\mathrm{m}^{3}$ in 2010 to 573 million $\mathrm{m}^{3}$ in 2020, and it could reach as much as 752 million $\mathrm{m}^{3}$ by 2030. These results are based on an assumed reduction of the share of wood in energy from renewable sources from 50\% in 2008 to $40 \%$ in 2020 . By 2025, the deficit of wood is expected to be 200 million $\mathrm{m}^{3}$, which will increase to 300 million by 2030. Due to a decreasing availability of wood, the use of particleboards is constantly growing in the furniture 
industry. They are also known as a form of hardboard and fibreboard called MDF (Medium Density Fibreboard), which are obtained from wood chips and a binder.

Over the last decade, there has been a deterioration in the mechanical properties of commercial particleboards in countries where forest resources are scarce. The main reason for this decline in quality is the increased use of recycled materials obtained from old furniture rather than using shredded natural wood. The use of recycled materials has been favoured, on the one hand, by the high cost of natural wood, and, on the other hand, by the fact that their use can help alleviate the shortage of raw material for the particleboard industry, thus helping to reduce the environmental impact of furniture production by reducing pressure on forests. National governments and the EU have promoted recycling at all stages. Therefore, the search for substitutes for natural wood, such as non-woody plants and the use of an organic binder, is currently of interest. Lignocellulosic materials from waste generated in agricultural activities could be used as a substitute for natural wood, but to achieve this, it is necessary to demonstrate that their fibres are suitable for manufacturing boards.

In order to reduce the consumption of natural wood, studies have been conducted regarding the production of particleboards using wood particles combined with different plant residues and using urea formaldehyde (UF) as an adhesive resin. The following materials have been used for this: sunflower stalks [3,4], peanut hull [5,6], walnut shell [7], walnut and almond shells [8], hazelnut shell [9], walnut and hazelnut shells [10], coffee parchment [11], cocoa industrial waste [12], rice straw [13], sycamore leaves [14], castor husk [15], tobacco stalk [16], apple and plum pruning [17] and grass clippings [18].

Reeds are the largest type of grass growing in Mediterranean regions, a wild plant to which no genotype selection or genetic improvement has been made. Giant reed is a weed that grows annually, reaching average heights of $4 \mathrm{~m}$ and a mean thickness of $4 \mathrm{~cm}$. It is a perennial plant that forms dense reed beds. Reed has been used in construction since ancient times in Mediterranean countries, but it is now in disuse. In cases where reeds grow on river banks, when the water level rises, they are uprooted and carried away on the current, forming large masses that block watercourses, causing flooding and sweeping away any structure that gets in their way; they are therefore an environmental problem.

There are also studies on the use of giant reed (Arundo donax L.) in particleboards with different adhesives such as urea formaldehyde [19], starch [20] and citric acid [21].

In this work, we study the possibilities of manufacturing hybrid wood and Arundo donax L. particleboards that could easily be produced in the wood board industry to counter the high dependence on wood imports by using an easily renewable resource such as the giant reed. The aim is to control a weed while at the same time obtaining a mixed board composed of wood and giant reed that could reduce the pressure on forest resources and create new job opportunities.

\section{Materials and Methods}

The materials used to manufacture boards were giant reed (Arundo donax L.) particles, pine wood particles from the particleboard industry and a binder consisting of $9 \%$ urea formaldehyde diluted in water and $0.4 \%$ ammonium sulphate with respect to the weight of the wood-reed particles.

The reed biomass came from clearing of the River Segura, in south-east Spain. The reeds were dried outdoors for 6 months. They were then cut and shredded in a blade mill.

The particle size distribution of pine wood and giant reed particles, classified according to sieve size, is shown in Table 1. The moisture content of both types of particles was $9 \%$.

The methodology followed is the manufacture of particleboards composed of different proportions of wood and giant reed $(0 \%, 50 \%, 70 \%$ and $100 \%)$. The mat was formed in a mould (600 $\mathrm{mm} \times 400 \mathrm{~mm})$ and was pressed and heated in a plate. Temperature and pressure time were $120^{\circ} \mathrm{C}$ and $4 \mathrm{~min}$, respectively. Pressure varied from 2.1 to $2.6 \mathrm{MPa}$. Temperatures ranging from 180 to $200{ }^{\circ} \mathrm{C}$ and pressures of around 3.5 MPa are used in the manufacture of commercial particleboards, so with the parameters selected for this work, we intended to use a manufacturing process involving lower energy consumption than the industrial process. 
Table 1. Size distributions of pine wood and giant reed particles.

\begin{tabular}{ccc}
\hline Sieve (mm) & Pine Wood Particles (\%) & Giant Reed Particles (\%) \\
\hline 4 & 36.4 & 24.9 \\
2 & 26.3 & 30.1 \\
1 & 27.1 & 20.4 \\
0.5 & 5.3 & 14.4 \\
0.25 & 2.0 & 6.5 \\
0.125 & 2.2 & 2.1 \\
0.063 & 0.4 & 1.5 \\
$<0.063$ & 0.3 & 0.1 \\
\hline
\end{tabular}

The boards consisted of a single layer with a thickness of approximately $6.5 \mathrm{~mm}$. The eight types of particleboards manufactured in this study are shown in Table 2. Samples of the type-B board series are shown in Figure 1.

Table 2. Types of board manufactured.

\begin{tabular}{ccccccc}
\hline $\begin{array}{c}\text { Type of } \\
\text { Board }\end{array}$ & $\begin{array}{c}\text { Proportion } \\
\text { of Pine } \\
\text { Wood } \\
\text { Particles } \mathbf{( \% )}\end{array}$ & $\begin{array}{c}\text { Proportion of } \\
\text { Giant Reed } \\
\text { Particles } \\
\mathbf{( \% )}\end{array}$ & $\begin{array}{c}\text { Pressure } \\
\mathbf{( M P a})\end{array}$ & $\begin{array}{c}\text { Time } \\
(\mathbf{m i n})\end{array}$ & $\begin{array}{c}\text { Temperature } \\
\left({ }^{\circ} \mathbf{C}\right)\end{array}$ & $\begin{array}{c}\text { Number of } \\
\text { Boards }\end{array}$ \\
\hline A1 & 100 & 0 & & & \\
A2 & 50 & 50 & 2.1 & & & \\
A3 & 30 & 70 & & & \\
A4 & 0 & 100 & & & \\
B1 & 100 & 0 & & & \\
B2 & 50 & 50 & 2.6 & & \\
B3 & 30 & 70 & & & \\
B4 & 0 & 100 & & & \\
\hline
\end{tabular}

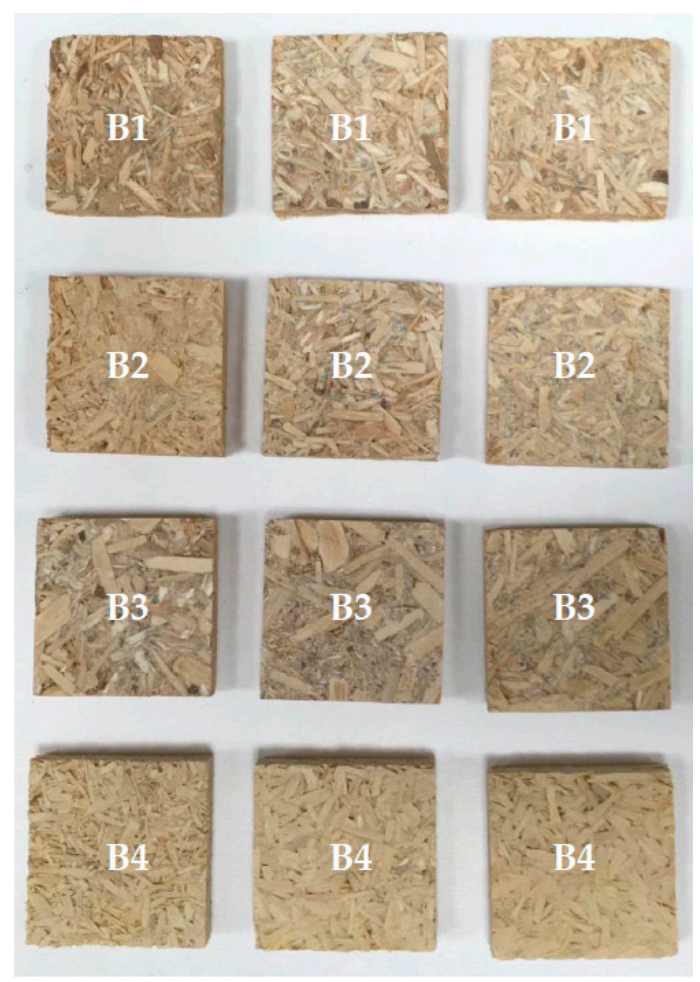

Figure 1. Photograph of the sample boards tested, measuring $50 \times 50 \mathrm{~mm}$. 
The European standards for wood particleboards [22] were used to determine the properties. The properties of the boards measured according to the European standards were: density [23], thickness swelling (TS) and water absorption (WA) after 2 and $24 \mathrm{~h}$ immersed in water [24], internal bonding strength (IB) [25], modulus of elasticity (MOE) and modulus of rupture (MOR) [26] and screw holding strength (SH) [27]. The boards were evaluated according to the European standard [28]. The thermal conductivity was measured using the heat flow meter method [29].

Before testing, the samples were placed in a JP Selecta refrigerated cabinet (model Medilow-L, Barcelona, Spain) at a temperature of $20{ }^{\circ} \mathrm{C}$ and a relative humidity of $65 \%$ for $24 \mathrm{~h}$.

Water content of the particleboards was obtained with an Imal laboratory moisture meter (model 200, Modena, Italy), whereas the immersion test was performed in a water tank heated to $20^{\circ} \mathrm{C}$.

An Imal universal testing machine (Model IB600, Modena, Italy) was used to perform the mechanical tests and a heat flow meter (NETZSCH Instruments Inc., Burlington, MA, USA) was used for the thermal conductivity tests.

For the statistical analysis of variance (ANOVA) at a significance level of $\alpha<0.05$, we used SPSS software for Windows v.26 (IBM, Chicago, IL, USA).

\section{Results and Discussion}

\subsection{Physical Properties}

Table 3 shows the density, thickness swelling and water absorption results according to the type of board.

Table 3. Physical properties of eight types of particleboards.

\begin{tabular}{cccccc}
\hline Type of Board & $\begin{array}{c}\text { Density } \\
\left(\mathbf{k g} / \mathbf{m}^{\mathbf{3}} \mathbf{)}\right.\end{array}$ & $\begin{array}{c}\text { TS 2 } \mathbf{~} \\
\mathbf{( \% )}\end{array}$ & $\begin{array}{c}\text { TS 24 h } \\
\mathbf{( \% )}\end{array}$ & $\begin{array}{c}\text { WA 2 h } \\
\mathbf{( \% )}\end{array}$ & $\begin{array}{c}\text { WA 24 h } \\
\mathbf{( \% )}\end{array}$ \\
\hline \multirow{2}{*}{ A1 } & 842.91 & 26.04 & 27.70 & 53.52 & 52.08 \\
& $(5.93)$ & $(0.57)$ & $(0.95)$ & $(4.80)$ & $(0.81)$ \\
A2 & 695.27 & 13.51 & 15.95 & 57.55 & 63.59 \\
& $(22.39)$ & $(0.52)$ & $(0.55)$ & $(5.46)$ & $(8.83)$ \\
A3 & 632.72 & 12.20 & 14.23 & 56.49 & 61.69 \\
& $(23.54)$ & $(0.41)$ & $(0.23)$ & $(1.52)$ & $(3.75)$ \\
A4 & 631.41 & 12.36 & 34.46 & 14.88 & 46.34 \\
& $(26.19)$ & $(0.82)$ & $(4.69)$ & $(0.78)$ & $(7.80)$ \\
B1 & 850.20 & 22.83 & 24.61 & 52.86 & 57.69 \\
& $(44.54)$ & $(2.07)$ & $(2.56)$ & $(5.23)$ & $(5.17)$ \\
B2 & 743.26 & 16.44 & 18.03 & 54.54 & 61.28 \\
& $(21.29)$ & $(1.60)$ & $(1.87)$ & $(3.37)$ & $(3.08)$ \\
B3 & 741.73 & 15.64 & 18.30 & 45.90 & 54.65 \\
& $(37.47)$ & $(1.29)$ & $(1.98)$ & $(6.67)$ & $(7.84)$ \\
B4 & 738.16 & 12.12 & 23.29 & 16.25 & 41.35 \\
& $(30.02)$ & $(3.45)$ & $(5.31)$ & $(2.59)$ & $(5.63)$ \\
\hline
\end{tabular}

TS: thickness swelling. WA: water absorption. ( ): standard deviation.

All the boards obtained can be considered to have a medium density. The highest density boards are type $\mathrm{A} 1$ and $\mathrm{B} 1$, with $100 \%$ wood particles from industry. Mixed boards with $70 \%$ reed particles (A3 and $\mathrm{B} 3$ ) produce the lowest density boards.

Type A2, A3, B2 and B3 mixed wood-giant reed boards produce lower \% thickness swelling (TS) values than those of the other boards and similar water absorption (WA) values to those obtained with $100 \%$ wood particleboards. Two regions of the giant reed plant can be distinguished: the outer region or epidermis, which has a regular pattern of normal, small, densely-walled epidermal cells, intermixed with oval-shaped siliceous cells, and the inner region, formed by cells with large, thin walls [30]. The greatest water absorption takes place in the inner region of the reed particles, since the composition 
of the epidermis offers greater resistance to this phenomenon. This would therefore explain the low water absorption after $2 \mathrm{~h}$ offered by type A4 and B4 boards (100\% reed particles).

The addition of giant reed particles improves the properties of $100 \%$ wood boards because it decreases the density and TS.

\subsection{Mechanical Properties}

Figure 2 shows the modulus of elasticity (MOE) and modulus of rupture (MOR) values obtained for the eight types of particleboard tested. The deviations from the values shown in Figure 2 are described in Supplementary Materials Table S1.

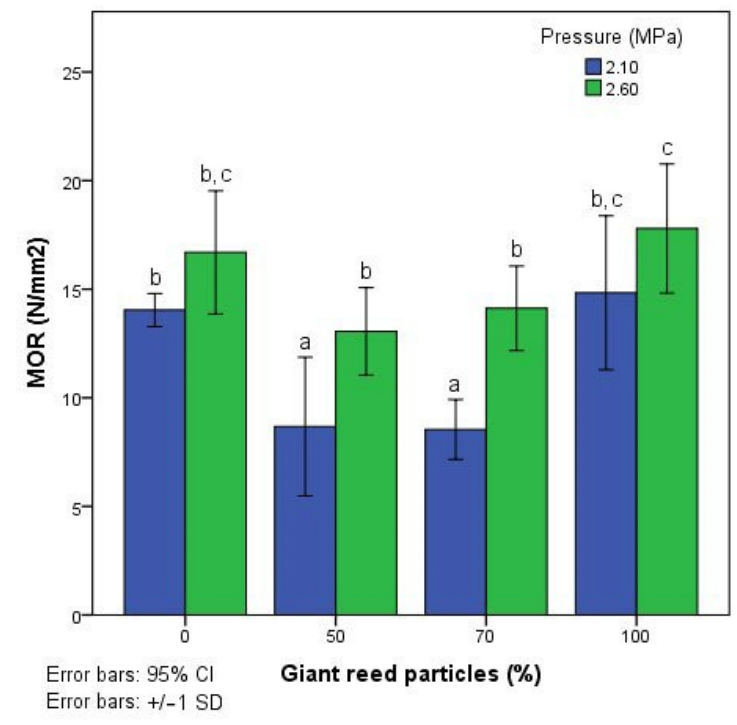

(a)

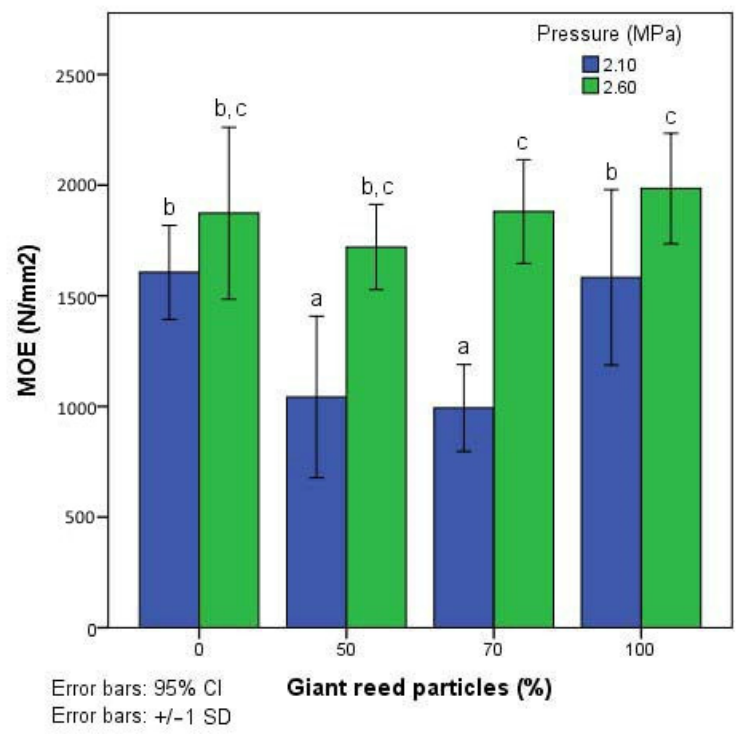

(b)

Figure 2. Modulus of rupture (MOR) and Modulus of elasticity (MOE) values of the eight particleboards. Values with the same letter are not significantly different based on Duncan's multiple range test at the 0.05 level. (a) MOR values; (b) MOE values.

The best results for MOR and MOE were attained when the composition contains $100 \%$ giant reed particles, achieving the best performance when the pressure applied was $2.6 \mathrm{MPa}$. With a pressure of 2.1 MPa for the mixed wood-reed boards the MOR and MOE decrease, and with a pressure of $2.6 \mathrm{MPa}$, the MOR and MOE values obtained are similar to those of the $100 \%$ wood particle boards. With $70 \%$ reed particles and a pressure of 2.6 MPa (type B3 board), an MOR value of $14.1 \mathrm{~N} / \mathrm{mm}^{2}$ and MOE value of $1880 \mathrm{~N} / \mathrm{mm}^{2}$ were obtained.

This same trend can be observed in the results obtained for internal bonding strength (IB) and screw hold (SH), as shown in Figure 3, where the best mechanical parameters were achieved with type B4 boards. In mixed boards, the addition of giant reed particles was found to increase the IB and SH. With $70 \%$ reed particles and a pressure of $2.6 \mathrm{MPa}$, an IB of $1.11 \mathrm{~N} / \mathrm{mm}^{2}$ and an SH of $90.24 \mathrm{~N} / \mathrm{mm}^{2}$ was obtained. The deviations from the values shown in Figure 3 are described in Supplementary Materials Table S1. 


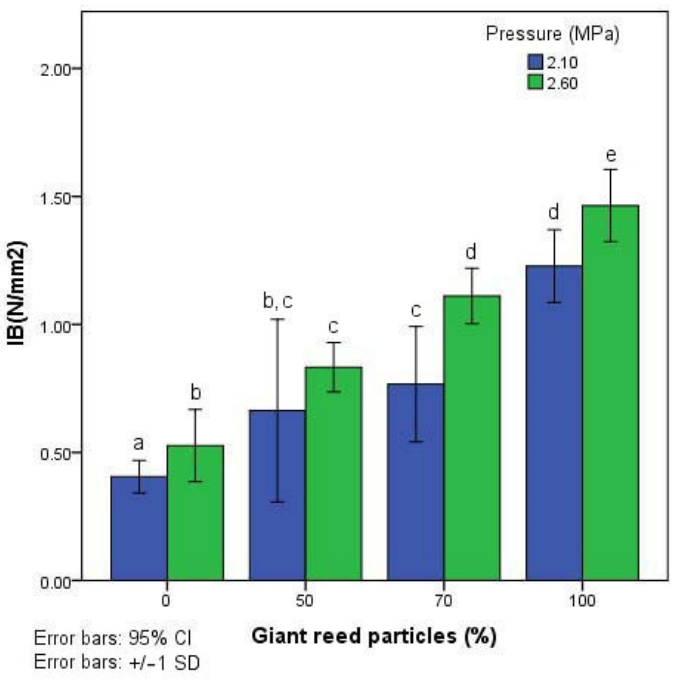

(a)

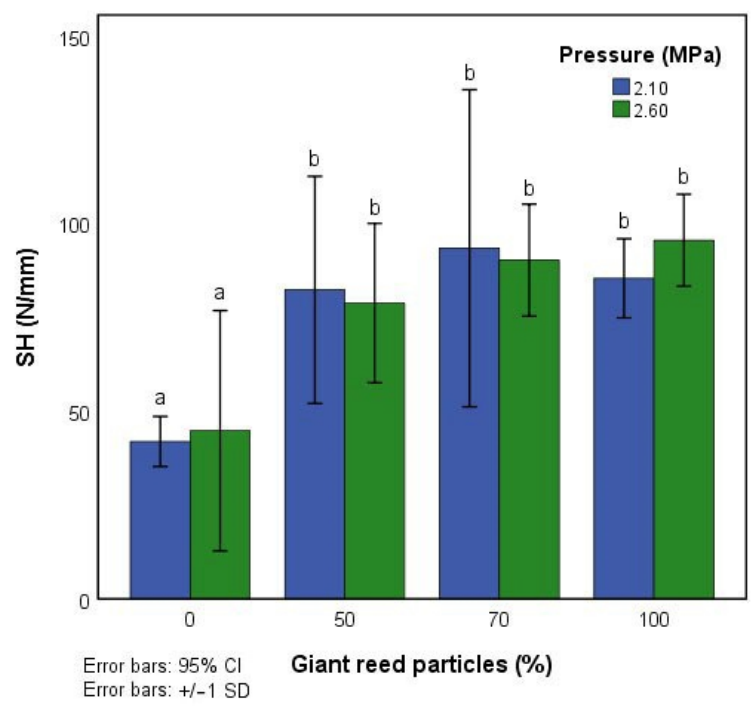

(b)

Figure 3. IB and SH values of the eight particleboards. Values with the same letter are no significantly different based on Duncan's multiple range test at the 0.05. (a) IB values; (b) SH values.

As can be seen from the ANOVA in Table 4, all the physical properties except for MOE depended on the percentage of giant reed added. The density, MOR, MOE and thermal conductivity also depended on the pressure applied.

Table 4. ANOVA of the results of the tests.

\begin{tabular}{|c|c|c|c|c|c|c|}
\hline Factor & Properties & $\begin{array}{l}\text { Sum of } \\
\text { Squares }\end{array}$ & d.f. & $\begin{array}{c}\text { Half } \\
\text { Quadratic }\end{array}$ & $\mathbf{F}$ & Sig. \\
\hline \multirow{8}{*}{$\begin{array}{c}\% \text { of reed } \\
\text { added }\end{array}$} & Density $\left(\mathrm{kg} / \mathrm{m}^{3}\right)$ & $65,724.901$ & 3 & $21,908.300$ & 6.252 & 0.002 \\
\hline & TS 24 h (\%) & 1260.236 & 3 & 420.079 & 17.876 & 0.000 \\
\hline & WA 24 h (\%) & 2054.597 & 3 & 684.866 & 16.689 & 0.000 \\
\hline & $\operatorname{MOR}\left(\mathrm{N} / \mathrm{mm}^{2}\right)$ & 162.434 & 3 & 54.145 & 5.832 & 0.002 \\
\hline & $\operatorname{MOE}\left(\mathrm{N} / \mathrm{mm}^{2}\right)$ & $533,881.466$ & 3 & $177,960.489$ & 1.187 & 0.329 \\
\hline & IB $\left(\mathrm{N} / \mathrm{mm}^{2}\right)$ & 3.451 & 3 & 1.150 & 40.724 & 0.000 \\
\hline & $\mathrm{SH}(\mathrm{N} / \mathrm{mm})$ & 9422.803 & 3 & 3140.934 & 12.105 & 0.000 \\
\hline & Thermal C. $(\mathrm{W} / \mathrm{m} \cdot \mathrm{K})$ & 0.002 & 3 & 0.001 & 12.108 & 0.000 \\
\hline \multirow{8}{*}{$\begin{array}{l}\text { Pressure } \\
\text { applied }\end{array}$} & Density $\left(\mathrm{kg} / \mathrm{m}^{3}\right)$ & $34,161.109$ & 1 & $34,161.109$ & 8.196 & 0.007 \\
\hline & TS $24 \mathrm{~h}(\%)$ & 98.413 & 1 & 98.413 & 1.835 & 0.184 \\
\hline & WA 24 h (\%) & 20.619 & 1 & 20.619 & 0.220 & 0.642 \\
\hline & $\operatorname{MOR}\left(\mathrm{N} / \mathrm{mm}^{2}\right)$ & 93.261 & 1 & 93.261 & 8.755 & 0.005 \\
\hline & $\operatorname{MOE}\left(\mathrm{N} / \mathrm{mm}^{2}\right)$ & $2,517,539.649$ & 1 & $2,517,539.649$ & 28.529 & 0.000 \\
\hline & IB $\left(\mathrm{N} / \mathrm{mm}^{2}\right)$ & 0.344 & 1 & 0.344 & 3.108 & 0.086 \\
\hline & $\mathrm{SH}(\mathrm{N} / \mathrm{mm})$ & 105.462 & 1 & 105.462 & 0.212 & 0.648 \\
\hline & Thermal C. $(\mathrm{W} / \mathrm{m} \cdot \mathrm{K})$ & 0.001 & 1 & 0.001 & 8.074 & 0.007 \\
\hline
\end{tabular}

d.f.: degrees of freedom. F: Fisher-Snedecor distribution. Sig.: significance.

The minimum requirements established by the European standard [28] for general use in dry conditions (Grade P1) are an IB of $0.28 \mathrm{~N} / \mathrm{mm}^{2}$ and a MOR of $10.5 \mathrm{~N} / \mathrm{mm}^{2}$. For furniture manufacturing (Grade P2), the minimum values required are an IB of $0.40 \mathrm{~N} / \mathrm{mm}^{2}$, a MOE of $1800 \mathrm{~N} / \mathrm{mm}^{2}$ and an MOR of $11.0 \mathrm{~N} / \mathrm{mm}^{2}$. For non-structural boards for use in humid conditions, the minimum requirements are an IB of $0.45 \mathrm{~N} / \mathrm{mm}^{2}$, a MOE of $2050 \mathrm{~N} / \mathrm{mm}^{2}$, a MOR of $15 \mathrm{~N} / \mathrm{mm}^{2}$ and $17 \%$ for TS at $24 \mathrm{~h}$. 
The best mechanical results for mixed boards are achieved with 30\% wood and $70 \%$ giant reed (board B3) at a pressure of 2.6 MPa. As shown in Table 5, board B2 could be classified as P1 and board $\mathrm{B} 3$ would achieve $\mathrm{P} 2$ classification.

Table 5. Mechanical and physical properties and classification of B2 and B3 boards according to the European regulations [28].

\begin{tabular}{|c|c|c|c|c|}
\hline Type of Board & $\operatorname{MOR}\left(\mathrm{N} / \mathrm{mm}^{2}\right)$ & $\operatorname{MOE}\left(\mathrm{N} / \mathrm{mm}^{2}\right)$ & IB $\left(\mathrm{N} / \mathrm{mm}^{2}\right)$ & TS 24 h (\%) \\
\hline B2 & 13.1 & 1.734 & 0.83 & 18.03 \\
\hline B3 & 14.1 & 1.880 & 1.11 & 18.30 \\
\hline Grade P1 & 10.5 & 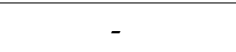 & 0.28 & - \\
\hline Grade P2 & 11.0 & 1.800 & 0.40 & - \\
\hline Grade P3 & 15.0 & 2.050 & 0.45 & 17.00 \\
\hline
\end{tabular}

Previous studies have manufactured particleboards made of walnut and almond shells [8] at $160{ }^{\circ} \mathrm{C}$, which obtained the required properties for use in indoor conditions. Boards manufactured with a ratio of 6:94 grass clippings with eucalyptus [18] have achieved the mechanical properties required for interior fittings, including furniture and general use. Scatolino et al. [11] concluded that the mechanical properties of the boards were improved by adding $10 \%$ coffee parchment particles and applying a temperature of $160^{\circ} \mathrm{C}$. Other works established that in order to meet the standards required for MOR, the maximum proportion of walnut shell [7] that should be added was $20 \%$ and for peanut shell [5], it was $25 \%$. Using castor husk as a raw material for the production of particleboards mixed with pine wood [15] and 8\% UF and applying a pressure of $3.92 \mathrm{MPa}$ and a temperature of $160{ }^{\circ} \mathrm{C}$ for $8 \mathrm{~min}$, the mechanical strength of the particleboards generally decreased as the content of castor husk increased. Up to $50 \%$ castor husk can be added to pine wood to produce particleboards that are suitable for indoor applications. Good mechanical performance is obtained in this work with $70 \%$ reed particles, and the boards obtained with the application of a temperature of $120{ }^{\circ} \mathrm{C}$ and a pressure of $2.6 \mathrm{MPa}$ for $4 \mathrm{~min}$ was found to achieve the mechanical performance requirements for indoor applications (including furniture) for use in dry conditions (Grade P2). Therefore, boards made of giant reed waste material have similar results of other studies of mixed boards while using a higher percentage of a lignocellulosic residue in a lower energy consumption process.

\subsection{Thermal Conductivity}

For the boards tested in this work, significant differences in thermal conductivity (Figure 4) were found between the types analysed, obtaining mean values between 0.0575 and $0.0804 \mathrm{~W} / \mathrm{m} \cdot \mathrm{K}$. They can therefore be considered as a good thermal insulating material, but it should be noted that B4 boards are the type with the best thermal properties. The addition of giant reed particles to the boards manufactured in this work provides similar thermal conductivity results to the boards using only wood particles. The deviations from the values shown in Figure 4 are described in Supplementary Materials Table S1.

Khedari et al. [31] performed a study using durian peel and coconut coir with $12 \%$ UF to manufacture particleboards, concluding that the boards had low thermal conductivity, ranging from 0.0540 to $0.1854 \mathrm{~W} / \mathrm{m} \cdot \mathrm{K}$; however, the mechanical properties obtained with these boards were quite low. 


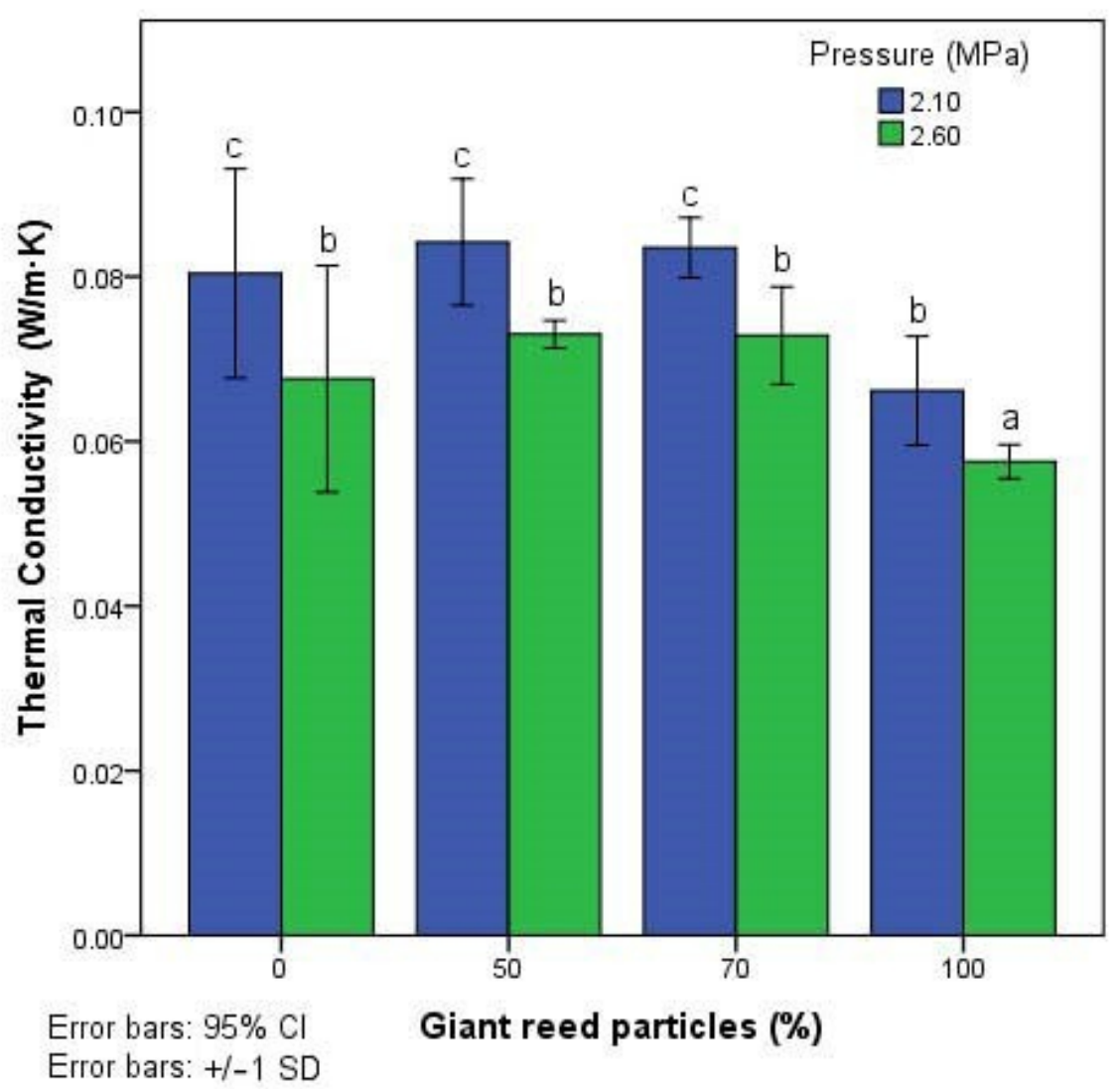

Figure 4. Thermal conductivity values of eight particleboards. Values with the same letter are no significantly different based on Duncan's multiple range test at the 0.05 .

\section{Conclusions}

By adding reed particles to wood particleboards, the density is reduced and the TS, IB and SH are improved. Therefore, giant reed is a plant fibre that can be added to wood particles to enhance the properties of wood boards.

The best results are achieved for mixed wood and giant reed boards manufactured with $70 \%$ reed particles and applying a pressure of $2.6 \mathrm{MPa}$, obtaining boards with a Grade P2 classification (for the manufacture of furniture and interior décor in dry conditions). These boards also have good thermal properties, so they could be used for interior divisions in buildings without the need for coatings. Future research should seek appropriate dosages and the application of some kind of water-repellent product that would allow us to manufacture boards that achieve the properties required for outdoor use.

The use of giant reed particles in the manufacturing of mixed wood boards could be an interesting alternative because it contributes to the development of more sustainable materials, involving lower energy consumption than industrial wood boards.

Supplementary Materials: The following are available online at http://www.mdpi.com/2071-1050/12/24/10469/s1, Table S1: Average results of mechanical and thermal properties.

Author Contributions: M.T.F.G. and C.E.F.-G. devised and designed the experiments; M.F.-V. and T.G.-O. performed the experiments; A.F.-G. and M.T.F.G. analysed the data; M.F.-V. contributed reagents/materials/ analytical tools; M.T.F.G. wrote the first draft of the paper. All authors have read and agreed to the published version of the manuscript.

Funding: This research was funded under Agreement No. 4/20 between the company Aitana, Actividades de Construcciones y Servicios, S.L. and Universidad Miguel Hernandez, Elche.

Acknowledgments: The authors would like to thank the company Aitana, Actividades de Construcciones y Servicios, S.L. for its support by signing Agreement No. 4/20 with Universidad Miguel Hernández, Elche on 20 December 2019. 
Conflicts of Interest: The authors declare no conflict of interest.

\section{References}

1. FAO. El Estado de los Bosques en el Mundo; Organización de las Naciones Unidas para la Alimentación y la Agricultura: Rome, Italy, 2014.

2. Mantau, U.; Saal, U.; Prins, K.; Steierer, F.; Lindner, M.; Verkerk, H.; Eggers, J.; Leek, N.; Oldenburguer, J.; Asikainen, A.; et al. Real Potential for Changes in Growth and Use of EU Forests; EUwood: Hamburg, Germany, 2010.

3. Bektas, I.; Güler, C.; Kalaycioğlu, H.; Mengeloglu, F.; Nacar, M. The Manufacture of Particleboards using Sunflower Stalks (helianthus annuus L.) And Poplar Wood (populus alba L.). J. Compos. Mater. 2005, 39, 467-473. [CrossRef]

4. Guler, C.; Bektas, I.; Kalaycioglu, H. The experimental particleboard manufacture from sunflower stalks (Helianthus annuus L.) and Calabrian pine (Pinus brutia Ten.). Forest Prod. J. 2005, 56, 56-60.

5. Guler, C.; Copur, Y.; Tascioglu, C. The manufacture of particleboards using mixture of peanut hull (Arachis hypoqaea L.) and European Black pine (Pinus nigra Arnold) wood chips. Bioresour. Technol. 2008, 99, 2893-2897. [CrossRef] [PubMed]

6. Guler, C.; Büyüksarı, Ü. Effect of production parameters on the physical and mechanical properties of particleboards made from peanut (Arachis hypogaea L.) hull. BioResources 2011, 6, 5027-5036.

7. Pirayesh, H.; Khazaeian, A.; Tabarsa, T. The potential for using walnut (Juglans regia L.) shell as a raw material for wood-based particleboard manufacturing. Compos. Part B Eng. 2012, 43, 3276-3280. [CrossRef]

8. Pirayesh, H.; Khanjanzadeh, H.; Salari, A. Effect of using walnut/almond shells on the physical, mechanical properties and formaldehyde emission of particleboard. Compos. Part B Eng. 2013, 45, 858-863. [CrossRef]

9. Çöpür, Y.; Güler, C.; Akgül, M.; Taşçığlu, C. Some chemical properties of hazelnut husk and its suitability for particleboard production. Build. Environ. 2007, 42, 2568-2572. [CrossRef]

10. Barbu, M.C.; Sepperer, T.; Tudor, E.M.; Petutschnigg, A. Walnut and Hazelnut Shells: Untapped Industrial Resources and Their Suitability in Lignocellulosic Composites. Appl. Sci. 2020, 10, 6340. [CrossRef]

11. Scatolino, M.V.; de Oliveira Costa, A.; Júnior, J.B.G.; de Paula Protásio, T.; Mendes, R.F.; Mendes, L.M. Eucalyptus wood and coffee parchment for particleboard production: Physical and mechanical properties. Cienc. Agrotech. 2017, 41, 139-146. [CrossRef]

12. De Araújo Veloso, M.C.R.; Pires, M.R.; Villela, L.S.; Scatolino, M.V.; de Paula Protásio, T.; Mendes, L.M.; Júnior, J.B.G. Potential destination of Brazilian cocoa agro-industrial wastes for production of materials with high added value. Waste Manag. 2020, 118, 36-44. [CrossRef]

13. Yang, H.-S.; Kim, D.-J.; Kim, H.-J. Rice straw-wood particle composite for sound absorbing wooden construction materials. Bioresour. Technol. 2003, 86, 117-121. [CrossRef]

14. Pirayesh, H.; Moradpour, P.; Sepahvand, S. Particleboard from wood particles and sycamore leaves: Physico-mechanical properties. Eng. Agric. Eviron. Food 2015, 8, 38-43. [CrossRef]

15. Silva, D.W.; Scatolino, M.V.; do Prado, N.R.T.; Mendes, R.F.; Mendes, L.M. Addition of different proportions of castor husk and pine wood in particleboards. Waste Biomass Valoris. 2018, 9, 139-145. [CrossRef]

16. Jimenez, J.J.P.; Acda, M.N.; Razal, R.A.; Abasolo, W.P.; Hernandez, H.P.; Elepaño, A.R. Effect of tobacco stalk additive particle size on the bond strength and formaldehyde emission of urea formaldehyde bonded plywood. Philipp. J. Sci. 2020, 149, 351-360.

17. Kowaluk, G.; Szymanowski, K.; Kozlowski, P.; Kukula, W.; Sala, C.; Robles, E.; Czarniak, P. Functional assessment of particleboards made of apple and plum orchard pruning. Waste Biomass Valoris. 2020, 11, 2877-2886. [CrossRef]

18. Nemli, G.; Demirel, S.; Gümüşkaya, E.; Aslan, M.; Acar, C. Feasibility of incorporating waste grass clippings (Lolium perenne L.) in particleboard composites. Waste Manag. 2009, 29, 1129-1131. [CrossRef]

19. García-Ortuño, T.; Andréu-Rodríguez, J.; Ferrández-García, M.T.; Ferrández-Villena, M.; Ferrández-García, C.E. Evaluation of the physical and mechanical properties of particleboard made from giant reed (Arundo donax L.). BioResources 2011, 6, 477-486.

20. Ferrández-García, C.E.; Andreu-Rodríguez, J.; Ferrández-García, M.T.; Ferrández-Villena, M.; García-Ortuño, T. Panels made from giant reed bonded with non-modified starches. BioResources 2012, 7, 5904-5916. [CrossRef] 
21. Ferrandez-Garcia, M.T.; Ferrandez-Garcia, C.E.; Garcia-Ortuño, T.; Ferrandez-Garcia, A.; Ferrandez-Villena, M. Experimental Evaluation of a New Giant Reed (Arundo donax L.). Composite Using Citric Acid as a Natural Binder. Agronomy 2019, 9, 882.

22. European Committee for Standardization. EN 309. Particleboards. Definitions and Classification; European Committee for Standardization: Brussels, Belgium, 2005.

23. European Committee for Standardization. EN 323. Wood-Based Panels. Determination of Density; European Committee for Standardization: Brussels, Belgium, 1993.

24. European Committee for Standardization. EN 317. Particleboards and Fibreboards. Determination of Swelling in Thickness after Immersion in Water; European Committee for Standardization: Brussels, Belgium, 1993.

25. European Committee for Standardization. EN 319. Particleboards and Fibreboards. Determination of Tensile Strength Perpendicular to the Plane of de Board; European Committee for Standardization: Brussels, Belgium, 1993.

26. European Committee for Standardization. EN 310. Wood-Based Panels. Determination of Modulus of Elasticity in Bending and of Bending Strength; European Committee for Standardization: Brussels, Belgium, 1993.

27. European Committee for Standardization. EN 320. Particleboards and Fibreboards_Determination of Resistance to Axial Withdrawal of Screw; European Committee for Standardization: Brussels, Belgium, 2011.

28. European Committee for Standardization. EN 312. Particleboards. Specifications; European Committee for Standardization: Brussels, Belgium, 2010.

29. European Committee for Standardization. EN 12667. Thermal Performance of Building Materials and Products: Determination of Thermal Resistance by Means of Guarded Hot Plate and Heat Flow Meter Methods: Products of High and Medium Thermal Resistance; European Committee for Standardization: Brussels, Belgium, 2001.

30. Obataya, E.; Norimoto, M. Acoustic properties of a reed (Arundo donax L.) used for the vibrating plate of a clarinet. J. Acoust. Soc. Am. 1999, 106, 1106-1110. [CrossRef]

31. Khedari, J.; Charoenvai, S.; Hirunlabh, J. New insulating particleboards from durian peel and coconut coir. Build. Environ. 2003, 38, 435-441. [CrossRef]

Publisher's Note: MDPI stays neutral with regard to jurisdictional claims in published maps and institutional affiliations.

(C) 2020 by the authors. Licensee MDPI, Basel, Switzerland. This article is an open access article distributed under the terms and conditions of the Creative Commons Attribution (CC BY) license (http://creativecommons.org/licenses/by/4.0/). 